\title{
Comparative Study of Information Display Media for Bank Indonesia Museum and Bank Mandiri Museum
}

\author{
Bilyan Putra Sari ${ }^{1, *}$ Andriyanto Wibisono ${ }^{2}$ \\ ${ }^{1}$ Faculty of Art and Design, ITB, Indonesia \\ ${ }^{2}$ Faculty of Art and Design, ITB, Indonesi \\ ${ }^{*}$ Corresponding author. Email: putrabilyan97@gmail.com
}

\begin{abstract}
Collection management is one way to make the museum a source of information and part of educational tourism. The reason for the selection of the Bank Indonesia Museum and Bank Mandiri Museum is because the type of collection about the history and objects of banking and museums that raise the theme of banking is relatively rare in Indonesia. The information media has a vital role in the success of a museum in communicating collectibles to its visitors. The difference in display information media between Bank Mandiri museum and Bank Indonesia Museum will be identified in this comparative study using comparative analysis method with the basic approach of designing museum visual communication design with some basic guidelines, namely: market share/visitor, design concept, design message, and design media. Visual communication design is a science that develops a form of visual communication language in the form of processing messages for social or commercial purposes, from individuals or groups addressed to other individuals or groups. Messages can be in the form of product information, services or ideas submitted to the target audience, to improve the understanding of collection objects contained in the museum. The purpose of this research is as a basis in decision making to produce an attractive, effective and functional display information media design in the Museum. Visual Communication Design not only gives art and fineness to objects, but also translates the soul that is relevant to the development of today's times and technologies.
\end{abstract}

Keywords: Museum, Information Media, Display, Visual Communication Design

\section{INTRODUCTION}

The museum is one element that stores cultural heritage that connects people from the past until now. Collection management is one way to realize the museum as a source of information. As part of the banking education tour, the managers of the Bank Mandiri Museum and the Bank Indonesia Museum must have the ability to manage the archives and collections in the museum and change the perspective and communication model applied. In the past, the communication model applied by museums in Indonesia was one-way mass communication. Messages and information are prepared by the museum and directed to visitors. In communication theory, there is no interaction between visitors and exhibitions. Visitors as passive spectators can only see objects showing off through dusty glass. Starting from the series of banking history in Indonesia, it takes efforts to keep the historical series from being cut off. This is behind the establishment of a banking museum. [1]

Bank Indonesia and Bank Mandiri established a banking museum that preserves and preserves cultural heritage, history, and banking information. The collections at the Bank Indonesia Museum and Bank Mandiri are expected to be useful not only for reviving the historical and cultural values contained in them but also as a trigger for the progress of the national banking world in general. As part of the banking education tour, information management at the Bank 
Mandiri and Bank Indonesia Museums must have the ability to manage existing collections by the aims and objectives of educational tourism. Information management of collectibles in the Museum of Bank Indonesia and Bank Mandiri can be done by selecting an effective display media to make it easier for visitors to understand information about collectibles. The selection of the display must be done systematically and in line so that visitors can easily understand the information on the object of the collection. A display is a visual aid that conveys information to visitors by presenting visually through the sense of sight. In addition, the information media of collectibles is also influenced by the design of the appearance. The display functions as a communication system that connects the information contained in the collection object with the visitors who see it.

Currently, the museum needs to have an understanding of Visual Communication Design in managing the messages or information contained in the museum, to improve the understanding of the collection of objects contained in the museum. In principle, Visual Communication Design is a design to convey the mindset of the delivery of messages to the recipient of the message, in the form of a communicative, effective, efficient, and precise visual form, patterned and integrated and aesthetic, through certain media to change the attitude of the target position. [2] Based on the concept of presentation of the museum Directorate of Museums (Directorate General of History and Antiquities, Ministry of Culture and Tourism), There are several things in understanding the design of visual communication in the museum, namely: (1) Know the concept of visual communication design as the basis of design/design and communication strategy collection. (2) Get to know graphic design (visual communication design) and visual language as visual processing of information data. (3) Know the technical principles, informatics technology process, and management information system. (4) Understand element graphic design as an effective, efficient, communicative, and aesthetically creative message delivery tool in the context of policy/planning/strategy concepts and implementation and evaluation, oriented towards museum visitors. (5) Understand communication strategies, psychology, and social/cultural anthropology. (6) Understanding some new media, especially the world of media/cyberspace and technical, namely: Audiovisual animation (mix media) \& Interactive media and web/website are commonly used to complete e-media and mix media/multimedia. (7) Mastering the concept of visual communication design and global marketing universally. Mastering the process and design techniques that can anticipate development.

Visual communication design can used as a means of presentation to the collection of objects contained in the museum to convey the message, get attention (attention) from the eyes (visually) and make the message can be more easily understood and remembered; for example, the use of media with a touch of digital technology on the media information display such as interactive media, this technology is very suitable to be applied in museums and can be applied to various media such as an interactive wall, interactive glass, and interactive floor. This technology consists of applications that can be any application according to your wishes, and games can also. It is then connected with a projector to be displayed on one of the media in the museum. [3] The use of digital technology such as this interactive in museums makes the museum more interesting to visit. According to the Directorate of Museums (Directorate General of History and Antiquities, Ministry of Culture and Tourism), The Functions and Roles of Visual Communication Design in the Museum Context are as follows: (1) A means of museum identification. A museum identity can tell what a museum is like, or where it came from. Likewise, an object, product, or institution, if it has an identity, will be able to reflect the quality of the product or service and be easily recognizable, both by the producer and the consumer. We will more easily remember the museum $\mathrm{X}$ or $\mathrm{Y}$, which has an identity than the museum without a clear identity of course. If visual communication design is used to identify institutions such as museums, for example, it will be easier for people to remember, identify and visit museums $\mathrm{X}$ or $\mathrm{Y}$, and understand what the collections are like. (2) Means of information and instructions, visual communication design aims to show the relationship between one thing and another in directions, directions, positions, and scales, for example, maps, diagrams, symbols, and directions. Information will be useful if it is communicated to the right people, in an understandable form, and presented logically and consistently. The symbols that we encounter every day such as traffic signs and signs, symbols in public places such as public telephones, toilets, restaurants, and others must be informative and communicative, can be read and understood by people from various backgrounds. back and circle. This is again one of the reasons why visual communication design must be 
universal. (3) Means of presentation and promotion, The purpose of visual communication design as a means of presentation and promotion is to convey messages, get attention (attention) from the eyes (visually) and make the message memorable; for example, posters. The use of images and words required is very little, has one meaning, and is impressive. Generally, to achieve this goal, the images and words used are persuasive and attractive, because the end goal is to sell a product or service. [4]

\section{METHODOLOGY}

The comparative study of display information media in this comparative study uses comparative research. The purpose of using this comparative research is to be able to: compare the similarities and differences of 2 or more facts and characteristics of the Bank Indonesia Museum with the Bank Mandiri Museum in presenting information on the collections displayed and determine which one is better or which one should be chosen in presenting information, This comparative research process goes through several stages such as; Determination of research problem formulation, Determination of groups that have the characteristics to be studied, Selection of comparison groups, Data collection, and data analysis. The following is a discussion of the process stages carried out by the comparative research method:

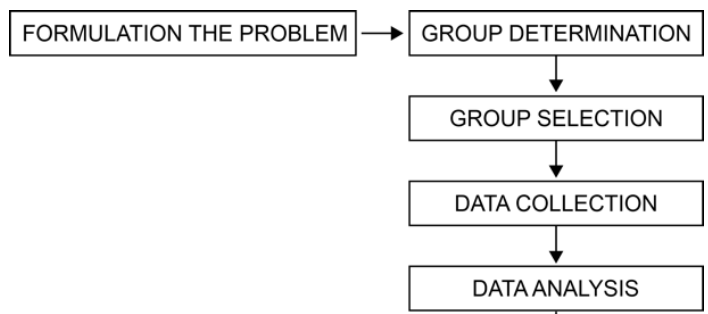

Figure 1 Diagram of comparative process

\subsection{Determining the formulation of the problem}

In a research proposal formulating a problem is the most important part and is quite challenging. Therefore, based on the background that has been described, several formulations of the problem in this study were formulated, namely: (1) How far is the representation of the display information media at the banking museum in Indonesia. (2) are there any differences and similarities in the representation of the information display media at the Bank Indonesia
Museum and the Bank Mandiri Museum in communicating the collections present at the museum.

\subsection{Determination of the group}

In this study, we chose the Bank Indonesia museum and the Bank Mandiri Museum because the types of collections and objects presented have the same theme and discussion and because the locations of the Bank Indonesia Museum and the Bank Mandiri Museum are close to each other, namely in the Jakarta Old Town area.

\subsection{Group Selection}

In this study, we chose the Bank Indonesia Museum and the Bank Mandiri Museum because the types of collections and objects presented have the same theme and discussion.

\subsection{Data Collection}

Comparative study of display information media in this comparative study uses data collection through observations made by virtual tours and literature studies. The data collected is then described and then evaluated based on the basic criteria of visual communication design at the museum.

\subsection{Data Analysis}

After the data has been collected, then an analysis is carried out by identifying the comparison of similarities and differences in the representation of the information display media at the Bank Mandiri Museum and the Bank Indonesia Museum using the basic design of Visual Communication Design at the Museum. Based on the Directorate of Museums (Directorate General of History and Antiquities, Ministry of Culture and Tourism), the basis for designing a museum's visual communication design requires several basic guidelines that need to be known, namely: (1) Market share/visitors. (2) Design Concept. (3) Design Message. (4) Design Media.

\section{RESULT AND DISCUSSION}

\subsection{Bank Indonesia Museum}




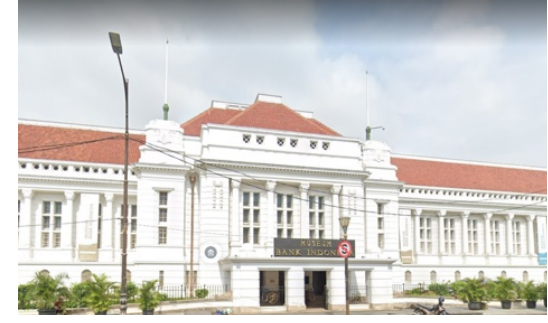

Figure 2 Bank Indonesia Museum

The Bank Indonesia Museum (MBI) has various forms of exhibitions in it. These attractions are obtained, among others, from the MBI building which is considered historic, the architectural elements of the charming building, unique diorama exhibitions, educational exhibition displays, and currency collections, or known as numismatics. From this diversity, of course, the MBI exhibition wants to convey and share information with the audience. Telling stories and communicating through storytelling in the form of narratives titled historical timelines owned by Bank Indonesia which are continuous with the history of the development of the Indonesian nation from one incident to another until now. This is seen by MBI as a responsibility as an institution that runs informal education programs for the audience, from the exhibitions displayed. The forms of timeline narratives that have historical value from Bank Indonesia were conveyed by MBI, one of which was through a display panel medium that brought the audience to the MBI exhibition. The medium panel display is designed in such a way by MBI to accommodate stories about the history of Bank Indonesia, communicate stories in the form of ideas or verbally in written, printed, or electronic terms that can be read and as evidence of the authenticity of stories or narratives in terms of informal education regarding the history of Bank Indonesia and Indonesian nation. [1]

The presentation of information at the Bank Indonesia museum is packaged in such a way by utilizing modern technology and multimedia, such as electronic displays, static displays, plasma televisions, and dioramas to create visitor convenience in enjoying the Bank Indonesia Museum. Besides that, there are also facts and collections of historical objects in the period before the formation of Bank Indonesia, such as during the Nusantara kingdoms, including a collection of numismatic money which is also displayed interestingly. Medium panel display here can be categorized in the Museum Information System which produces the scope and role of information media used in museums.

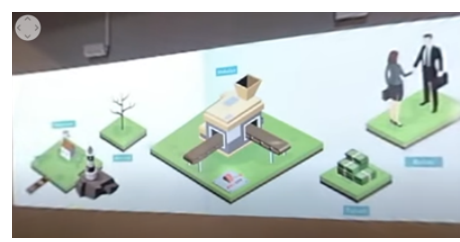

Figure 3 Interactive Display with interactive multimedia In the Islamic banking space MBI

In the sharia banking room, visitors do not only read the text on the static display but in this room, there are also interactive multimedia with a large screen where visitors can find out more information about the differences between traditional banks and Modern banks. And in this room, there is also a Magic Book display information media which is digital technology with Dopri sensors that help visitors to get information about the history of the formation of Islamic banks. When viewed from the use of information media on displays that were present at the Bank Indonesia Museum, various types of new media have been implemented as a means of delivering messages that are effective, efficient, communicative, and aesthetically creative in the context of the concept of policy/planning/strategy and implementation and evaluation, which are oriented towards museum visitors.

\subsection{Bank Mandiri Museum}

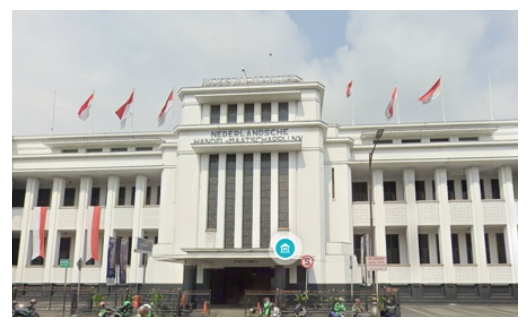

Figure 4 Bank Mandiri Museum

Starting from the historical series of the predecessor banks and the merged banks that merged into Bank Mandiri, it is necessary to make efforts to keep the historical series unbroken. This is the background behind the establishment of a banking museum. Bank Mandiri established a banking museum that preserves and cares for the cultural heritage and materials of its predecessor banks to become Bank Mandiri. [5] 
The collection is expected to be useful not only to commemorate the historical and cultural values contained therein but also as a trigger for the progress of the national banking world in general and Bank Mandiri in particular. As part of the banking education tour, the manager of the Bank Mandiri Museum must have the ability to manage the collections in the museum to suit the aims and objectives of the educational tour. The management carried out is by arranging the flow of visits and arranging museum collections in such a way as to provide comfort and convenience for visitors/tourists to understand the contents and meaning of the Bank Mandiri Museum. Arrangement of the flow of visits and arrangement of collections must be done systematically and in line so that visitors can easily interpret the contents of museum collections. [5]

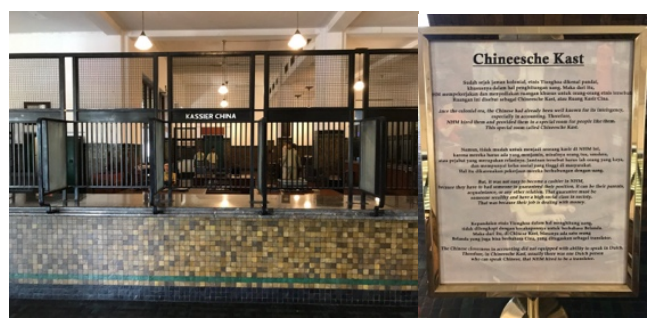

Figure 5 China Cashier Room

Information Display Media MBM

Source: https://id.foursquare.com/

The collection materials at the Bank Mandiri Museum consist of types of bank operational equipment, securities, numismatics, historical archives, and other types of collections such as bank operational support equipment and library materials. However, when viewed from the results of the virtual tour conducted by the author, the presentation of information display media contained in the Mandiri Bank Museum is still minimal in the use of technology-based or interactive media. One example in the Chinese cashier room here, visitors are only presented with a diorama showing the condition of the room in ancient times and only equipped with Display information media using media that only contains information about the room in Indonesian and English. The display information media contained in the Bank Mandiri museum still uses the type of static display information media which only contains writing that becomes less attractive in conveying information on the collections contained in the independent museum so that it seems boring and monotonous. In every exhibition room at the Mandiri Bank Museum, it is very rare to find effective and interesting information media.

\subsection{Comparison}

Table 1. Comparison table with the DKV museum approach

\begin{tabular}{|l|l|}
\hline \multicolumn{1}{|c|}{ DKV Guidelines } & Bank Indonesia Museum \\
\hline Media Information & \\
\hline Market share/Visitors & $\begin{array}{l}\text { The general public with } \\
\text { various backgrounds }\end{array}$ \\
\hline Design concept. & $\begin{array}{l}\text { Two-way interpersonal } \\
\text { communication through } \\
\text { education, and interactive } \\
\text { exhibitions have } \\
\text { entertainment, recreation, } \\
\text { and relaxation values }\end{array}$ \\
\hline Design Media & $\begin{array}{l}\text { Information about the history } \\
\text { of the formation of Islamic } \\
\text { banks }\end{array}$ \\
\hline Design Message \\
Dopri sensors.
\end{tabular}

\section{\begin{tabular}{l|l} 
DKV Guidelines & Bank Mandiri Museum
\end{tabular}}

\begin{tabular}{|l|l|}
\hline $\begin{array}{l}\text { Media Information } \\
\text { Display }\end{array}$ & $\begin{array}{l}\text { The general public with } \\
\text { various backgrounds }\end{array}$ \\
\hline Market share/Visitors & $\begin{array}{l}\text { One-way mass } \\
\text { communication. Where } \\
\text { messages and information } \\
\text { are prepared by the museum } \\
\text { and directed to visitors }\end{array}$ \\
\hline Design concept. & $\begin{array}{l}\text { Information about records of } \\
\text { all financial transactions }\end{array}$ \\
\hline Design Message & $\begin{array}{l}\text { Static Media using paper } \\
\text { containing text. }\end{array}$ \\
\hline Design Media &
\end{tabular}


Table 2. Comparison table with the DKV museum approach

\begin{tabular}{|l|l|}
\hline DKV Guidelines & Bank Indonesia Museum \\
\hline $\begin{array}{l}\text { Media } \\
\text { Display }\end{array}$ & $\begin{array}{l}\text { The general public with } \\
\text { various backgrounds }\end{array}$ \\
\hline $\begin{array}{l}\text { Market } \\
\text { share/Visitors }\end{array}$ & $\begin{array}{l}\text { Two-way interpersonal } \\
\text { communication through } \\
\text { education, and interactive } \\
\text { exhibitions have } \\
\text { entertainment, recreation, } \\
\text { and relaxation values }\end{array}$ \\
\hline Design concept. & $\begin{array}{l}\text { Information about inflation in } \\
\text { simple terms }\end{array}$ \\
\hline Design Message \\
\hline Design Media & $\begin{array}{l}\text { Digital Media with mini } \\
\text { theater accompanied by } \\
\text { animated video and audio }\end{array}$ \\
\hline
\end{tabular}

\begin{tabular}{|l|l|}
\hline DKV Guidelines & Bank Mandiri Museum \\
\hline $\begin{array}{l}\text { Media } \\
\text { Display }\end{array}$ & $\begin{array}{l}\text { The general public with } \\
\text { various backgrounds }\end{array}$ \\
\hline $\begin{array}{l}\text { Market } \\
\text { share/Visitors }\end{array}$ & $\begin{array}{l}\text { One-way mass } \\
\text { communication. Where } \\
\text { messages and information } \\
\text { are prepared by the museum } \\
\text { and directed to visitors }\end{array}$ \\
\hline Design concept \\
\hline Design Message & $\begin{array}{l}\text { Information about the history } \\
\text { of money cutting machines }\end{array}$ \\
\hline Design Media & $\begin{array}{l}\text { Static Media by using a } \\
\text { panel containing text. }\end{array}$ \\
\hline
\end{tabular}

\section{CONCLUSION}

Based on the results of the comparison of display information media, it can be seen that the Bank Indonesia Museum uses the type of intrapersonal communication on the display information media contained in the museum which is two-way in nature which can be achieved through educational programs, live/real interpretations, and interactive exhibitions through various communication media. visuals such as audio-visual, touch screen, and multimedia. Current technological advances support the development of this type of display. With the application of the interpersonal communication model, the Bank Indonesia Museum becomes more interesting and not boring.

This museum not only has an educational function but also has entertainment, recreation, and relaxation values so that the purpose of the visit from the public and the expectations of the community towards the Bank Indonesia Museum are well achieved and are in accordance with the current developments. Meanwhile, the Bank Mandiri Museum still uses the type of mass communication to display information media that is one-way. Messages and information are prepared by the bank Mandiri museum and directed to visitors. Where this is the absence of interaction between visitors and exhibitions or collections presented at the museum. Visitors only as passive spectators can only see the exhibits contained in the museum so that they seem monotonous, boring and not up to date with the times.

In modern times, museums have a way of attracting visitors by using a touch of digital technology on display information media so that the museum's image is not considered rigid for the current generation. The use of interactive digital technology in the museum, it makes the museum more interesting to visit. In Indonesia, there are already several museums that use digital technology in conveying information on the collections presented at the museum for interactive learning to be able to invite visitors to involve their mind, sight, hearing, and skills. The purpose of this comparative study is to obtain a reference/reference for decision making in producing an attractive, effective, and functional display media design for the Museum. With interactive displays at the museum, it helps visitors to better understand the information to be conveyed. 
The past was a time when changes appeared massively everywhere to support technological developments. One of them gave birth to digital technology. Digital is closely related to the computer systems used to develop solutions in the past. So that digital technology can be interpreted as the use of new applications to solve problems and provide solutions [6]

\section{ACKNOWLEDGMENTS}

Thank you to the lecturers of the Faculty of Art and Design, ITB, especially Dr. Andriyanto Wibisono, M.Sn, who has provided direction and guidance in completing this research and friends, the Best Scholarship class of 2020 who always provide support and enthusiasm so that this research can be completed.

\section{REFERENCES}

[1] I. S. Hartanto, A. Joedawinata, A, Kajian Media Informasi Panel Display Pada Pameran Museum Bank Indonesia, Jurnal Seni \& Reka Rancang, 2020, pp. 2.

[2] Direktorat Pelindungan Kebudayaan Kebudayaan.Kemendikbud.go.id, July 12, 2021, [Online]. Avaliable from: https://kebudayaan.kemdikbud.go.id/dpk/dasarperancangan-desain-komunikasi-visualmuseum/

[3] Direktorat Pelindungan Kebudayaan Kebudayaan.Kemendikbud.go.id, July 12, 2021, [Online]. Avaliable from: https://kebudayaan.kemdikbud.go.id/dpk/perlu nya- pemahaman-desain- komunikasi-visual-dimuseum/

[4] Direktorat Pelindungan Kebudayaan Kebudayaan.Kemendikbud.go.id, July 12, 2021, [Online]. Avaliable from: https://kebudayaan.kemdikbud.go.id/dpk/ fungsi-dan-peran-desain-komunikasi-visualdalam-kontek-museum/

[5] N. Irdana, S. Kumarawarman, Konsep Penataan Koleksi Museum Untuk Mempermudah Pemahaman Wisatawan Dalam Wisata Edukasi Arsip Dan Koleksi Perbankan di Museum Bank Mandiri Jakarta, Diplomatika, 2018, pp. 4.
[6] Y. R. Patandean, P. E. Indrajit, Digital Transformation, Penerbit Andi, Yogyakarta, 2020.

[7] T. Fullerton, Game Design Workshop A Playcentric approach to creating innovative games 2nd, Morgan Kaufman Publisher, Burlington, 2008. 